\title{
Strategi Pendidikan Toleransi Beragama dan Implikasinya terhadap Keutuhan NKRI di Bangka Belitung
}

\author{
Suparta \\ Pascasarjana IAIN Syaikh Abdurrahman Siddik Bangka Belitung \\ partasuparta23@yahoo.co.id
}

\begin{abstract}
Abstrack
This article aims to review and describe the strategy of religious tolerance education and its impact on the integrity of the Negara Kesatuan Republik Indonesia (NKRI) in Bangka Belitung. In the Bangka Belitung Islands, the life of the people is very heterogeneous and has a high level of plurality. There are many portraits of the diversity of ethnicities, cultures, religions, ethnicities and languages that are integrated into the social dynamics of the people in Bangka Belitung. Of course, this plurality has the potential to cause horizontal conflict in society. Therefore, to study and examine in depth this reality an in-depth interview technique is used to obtain clear information about the principles of religious tolerance from the perspective of Islam, Christianity, Buddhism, Hinduism, and Confucianism. As a result, there are three educational strategies that can be developed by religious communities in Bangka Belitung; first, the strategy of educating the internal religious community; second, the strategy of educating people to maintain harmony between fellow religious communities; and third, the strategy of educating people to maintain harmony with the government.
\end{abstract}

Artikel ini bertujuan untuk mengulas dan memaparkan strategi pendidikan toleransi beragama dan dampaknya terhadap keutuhan Negara Kesatuan Republik Indonesia (NKRI) di Bangka Belitung. Di Kepulauan Bangka Belitung kehidupan masyarakatnya sangat heterogen dan memiliki tingkat pluralitas yang tinggi. Ada banyak potret keragaman suku, budaya, agama, etnis, dan bahasa yang menyatu dalam dinamika sosial masyarakat di Bangka Belitung. Tentu, pluralitas tersebut berpotensi menimbulkan konflik horizontal di tengah masyarakat. Oleh karena itu untuk mengkaji dan menelaah secara mendalam realitas tersebut digunakan teknik wawancara mendalam untuk mendapatkan informasi yang jelas mengenai prinsip toleransi beragama dalam perspektif agama Islam, Kristen, Budha, Hindu, dan Konghucu. Hasilnya, ada tiga strategi pendidikan yang dapat dikembangkan oleh umat beragama yang ada di Bangka Belitung; pertama, strategi mendidik dalam internal umat beragama; kedua, strategi mendidik umat untuk menjaga kerukunan antara sesama umat beragama; dan ketiga, strategi mendidik umat untuk menjaga kerukuan dengan pemerintah.

Keywords: Strategy, Education, Tolerance, Social Harmony, Indonesia 


\section{A. Pendahuluan}

Bangka Belitung termasuk daerah yang memiliki keragaman agama yang sangat heterogen. Semua agama yang ada di Indonesia ada di Bangka Belitung, mulai dari agama Islam sebesar 81,83\%, Budha 8,71 \%, Kong $\mathrm{Hu} \mathrm{Cu} \mathrm{5,11 \% ,} \mathrm{Kristen} \mathrm{2,44 \% ,}$ Kristen Katolik 1.79\%, dan Hindu 0,13\%. ${ }^{1}$ Begitu juga dengan penduduknya, ada berbagai suku mulai dari suku Bangka, suku Jawa, suku Sunda, suku Bugis, suku Buton, suku Flores, suku Batak dan etnis keturunan dari China (30\%), serta masih banyak lagi suku lainnya. Keragaman ini menjadikan Kepulauan Bangka Belitung sebagai daerah yang memiliki tingkat pluralitas yang tinggi bila dibandingkan dengan daerah yang lainnya.

Jika banyaknya agama merupakan salah satu faktor terjadinya konflik, maka Provisinsi Kepulauan Bangka Belitung dapat dikategorisasikan daerah berpotensi rawan konflik. Oleh sebab itu, bila tidak ada wadah atau media yang bisa merukunkan keberagaman tersebut, maka tidak menutup kemungkinan konflik atas nama agama bisa terjadi. Seperti di Kabupaten Belitung, menurut Ramansyah semua agama yang ada di Belitung ini, mulai dari agama Islam, Kristen Protestan, Katolik, Hindu, Budha dan Konghucu dipertemukan dan dipersatukan dalam satu wadah yang disebut dengan FKUB (Forum Kerukunan Umat Beragama) ${ }^{2}$. Melalui wadah inilah semua para tokoh agama berkumpul dan bersatu untuk membicarakan semua persoalan yang ada korelasinya dengan persoalan agama masing-masing. Sejak adanya perhimpunan ini (FKUB), maka komplik agama atau yang ada hubungannya masalah isu isu keagamaan dapat diantisipasi. Dengan kata lain, ada pencegahan dini komplik, karena sebelum

\footnotetext{
${ }^{1}$ Sumber lihat http://www.kemendagri.go.id/pages/profil-daerah/provinsi/detail/19/ke pulauanbangka-belitung

${ }^{2}$ Drs. Ramansyah, MM, Ketua Forum Kerukunan Umat Beragama Kabupaten Belitung, Wawancara, pada tanggal 08 Juli 2018 jam 19.35. Ia mengatakan bahwa FKUB ini termasuk wadah yang sangat Efektif untuk mengendalikan berbagai komplik keagamaan di daerah. Ia mengatakan bahwa tak terbayangkan jika tidak ada wadah pemersatu ini, jika ada konflik maka penyelesaiannya sangat sulit. Sebab, jika setiap agama sudah mengedepankan ego agamanya masing masing, terutama yang bersinggungan dengan masalah ibadah maka bisa dengan cepat konflik agama itu terjadi. Misalnya masalah simbol ibadah antara agama Budha dan Konghucu, masing masing dari mereka mengatakan bahwa simbol simbol agama tersebut adalah milik agamanya masing masing. Jika tidak ada wadah ini (FKUB) maka dipastikan antara agama Budha dan Konghucu akan terjadi konflik yang tak berkesudahan. Akan tetapi dengan adanya wadah ini maka syukurlah konflik atau perbedaan di kedua agama ini dapat diselesaikan dengan cara bermusyawarah.
} 
komplik terjadi maka semua tokoh agama segera menyelesaikannya dengan jalan musyawarah.

Hal ini senada dengan H. Yohanda, Ia mengatakan bahwa selama adanya FKUB maka peta keagamaan yang ada hubungannya dengan komplik keagamaan sangat signifikan sebagai alat antisipasi komplik ${ }^{3}$. Hanya saja terkadang ada saja sebagian kelompok yang tidak suka dengan adanya FKUB ini. Mereka ada yang berasumsi bahwa keberadaan FKUB seolah merupakan sarana atau media pemikiran untuk menyamakan semua agama. ${ }^{4}$ Pemikiran ini menurut beliau salah karena agama sudah merupakan keyakinan masing-masing sehingga tidak bisa disamakan. Adapun yang berusaha disamakan di dalam organisasi ini (FKUB), adalah persepsi dalam peyelesaian maslah atau problem-problem yang berkaitan dengan isu SARA. Dengan kata lain, yang disamakan adalah pendapat dalam menyelesaikan masalah bukan menyamakan pemikiran dan keyakinan agamanya.

Senada dengan yang dikatakan oleh Drs. Iskandar, di Kabupaten Bangka Selatan semua agama sepakat melalui FKUB ini tidak boleh membahas tentang penyamaan persepsi tentang aqidah atau keyakinan agama masing-masing, apalagi memaksakan untuk sama tentang persoalan keyakinan beragama. Akan tetapi, dalam organisasi ini (FKUB) adalah tempat berinteraksi atau tempat bersdiskusi sekaligus ajang silaturahmi dengan semua tokoh agama yang khusus membicarakan tentang cara atau strategi para tokoh dalam penyelesaian komplik SARA. Sehingga forum ini mengedepankan solusi-solusi untuk mengatasi konflik tersebut dengan cara yang baik dan benar, dengan cara yang nyaman dan aman ${ }^{5}$.

Menurut H. Harahap agama yang ada di Bangka Barat termasuk lengkap. Mulai dari agama Islam, Kristen Protestan, Katolik, Budha, Hindu dan Konghucu. Namun

\footnotetext{
${ }^{3}$ H. Yohanda adalah Ketua FKUB Kabupaten Bangka Tengah, wawancara , pada tanggal 23 Agustus 2018 di kantor FKUB di Belakang Kementerian Agama Bangka Tengah

${ }^{4}$ Hal ini dirasakan juga oleh Drs. Ramansyah, MM, Ketua FKUB Kabupaten Belitung, ada sebagian para tokoh yang berasumsi bahwa keberadaan FKUB ini dianggap ajang atau tempat berkumpulnya orang - orang yang akan berusaha menyamakan semua agama adalah sama. Padahal menurut beliau FKUB ini hanyalah wadah para tokoh untuk berbicara, berdiskusi atau berdialog tentang permaslahan-permaslahan agama khususnya jika berkaitan dengan indikasi indikasi konflik agama. Dengan adanya FKUB ini maka konflik agama akan diantisipasi sedini nmungkin. Sebelum masalah tersebut menjadi maslaah yang besar yang akan menyebabkan konflik agama di tengah tengah masyarakat.

${ }^{5}$ Drs. Iskandar, Ketua FKUB Kabupaten Bangka Selatan, wawancara, pada tanggal 26 Juli 2018 di Ruang Kasubag TU Kementerian Agama Kabupaten Bangka Selatan, jam 10.00 WIB
} 
demikian sampai saat ini kata beliau belum pernah terjadi komplik atas nama agama. Toleransi yang sudah berjalan saat ini termasuk sangat baik, khususnya di kota Muntok. Hal ini dapat dilihat secara kasat mata, dengan adanya bangunan rumah ibadah yang berdampingan antara rumah ibadah umat Islam (masjid) dengan rumah ibadah umat Konghucu (klenteng) yang sudah berdiri puluhan tahun lamanya. Selain itu ada juga mesjid yang berdampingan dengan Greja (tempat ibadah umat Kristen) ${ }^{6}$. Adanya simbol rumah ibadah yang berdampingan ini, menunjukkan betapa rukunnya situasi keagamaan yang ada di daerah tersebut.

Berdasarkan beberapa hasil wawancara di atas memberikan isyarat yang jelas bahwa pemetaan keagamaan yang ada di beberapa kabupaten Kepulauan Bangka Belitung termasuk berada pada zona yang aman dari konflik. Namun demikian, jika tidak terpelihara dengan baik, apalagi disusupi oleh para oknum provokator konflik akan bisa berakibat fatal. Sebab, di setiap kabupaten memiliki keanekaragaman umat beragama serta beranekaragamnya suku dan ras. Untuk itu, mereka yang berada di pengurusan FKUB sedang membuat peta keagamanan dengan tiga zona, yaitu zona aman dari konflik (hijau), zona sedang dari konflik (zona kuning), dan zona bahaya dari konflik (zona merah).

Bagi daerah yang ditandai dengan zona aman atau hijau maka cukup dipelihara saja, bagi daerah yang ditandai dengan zona kuning maka mulai diadakan pendekatan dan pembinaan, sedangkan bagi daerah yang sudah ditandai dengan zona merah maka instensitas pembinaan dan pendekatannya diadakan secara terus-menerus, bahkan sudah melibatkan berbagai intansi terkait dalam pembinaannya, seperti dengan Kesbangpol, Kemenag, seluruh ormas keagagamaan dan juga bekerja sama dengan para penegak hukum baik dari pihak kepolisian, kejaksaan dan pengadilan. Dengan kata lain, diadakan solusi sedini mungkin sebelum komplik besar terjadi ${ }^{7}$.

\footnotetext{
${ }^{6}$ H. Harahap, sebagai Ketua FKUB Bangka Selatan, Wawancara, pada tanggal 01 Agustus 2018, bertempat di Ruang Kasubag TU Kementerian Agama Bangka Barat, Jam 11.00 WIB

${ }^{7}$ Hal ini disepakati oleh para Ketua FKUB se-Bangka Belitung, ketika masing masing diwawancarai di daerah mereka masing-masing. Seperti pak Drs. Ramansyah, MM di Belitung (Ketua FKUB Belitung), Drs. Iskandar (Ketua FKUB Bangka Selatan), H. Yohanda, Amd (Ketua FKUB Bangka Tengah), Drs. H. Husein Jaiz (Ketua FKUB Bangka), dan H. Harahap (Ketua FKUB Bangka Selatan)
} 


\section{B. Profil Lembaga Keagamaan Kepulauan Bangka Belitung}

Profil lembaga keagamaan yang akan dipaparkan disini adalah semua agama yang ada di Bangka Belitung. Mulai dari Agama Islam, Agama Kristen Protestan, Katolik, Budha, Hindu dan Konghucu. Namun, tidak semua agama di setiap Kabupaten memiliki lembaga keagamaan. Hal ini disebabkan dengan jumlah umatnya yang masih sangat sedikit, seperti agama hindu. Sehingga untuk agama hindu ini lembaga keagamaannya sangat terbatas.

Hal ini disebabkan oleh beberapa faktor; Pertama adalah masalah kuantitas umat. Ada agama tertentu yang memiliki umat sangat minim seperti agama hindu dan budha yang ada dibeberapa kabupaten. Seperti Hindu misalnya yang banyak penganutnya hanya ada di Belitung sementara di kabupaten lain tidak ada atau kalaupun ada hanya sedikit. Demikian juga dengan Agama Budha tidak semua kabupaten ada. Begitu juga dengan Agama Konghucu hanya ada dibeberapa tempat atau daerah saja sementara dibeberapa daerah lain tidak ada, kalaupun ada hanya sedikit.

Faktor kedua adalah faktor kualitas SDM. Untuk membuka sebuah lembaga keagamaan bukan hanya diperlukan banyaknya umat akan tetapi juga diperlukan SDM. Untuk itu, beberapa agama belum bisa mengadakan lembaga keagamaan dikarenakan disamping keterbatasan umatnya juga keterbatasan SDMnya. Hal ini terjadi pada Agama Konghucu, karena agama ini termasuk baru di Indonesia maka SDM yang dimiliki Agama Konghucu masih minim terutama SDM yang berkaitan dengan para Rahaniawannya. Salah satu penyebabnya adalah masih minimnya sarjana sarjana agama yang berbasis konghucu, karena memang beum banyak bahkan mungkin belum ada perguruan tinggi khusus yang membidangi pengajaran tentang agama konghucu. Berbeda dengan agama lain yang sudah banyak SDM-nya yang dikeluarkan dari perguruan tinggi, seperti dalam agama Islam ada STAIN, IAIN, UIN yaang negerinya dan perguruan tinggi Islam yang swasta juga sangat banyak, belum lagi pondok pesantrennya. Di agama Kristen demikian juga ada STAKN, IAKN, dan ada beberapa perguruan tinggi kristen dan lembaga-lembaga kristen lainnya seperti seminar dan lain sebagainya. Di agama Hindu juga ada STAHN dan IAHN dan juga ada perguruan tinggi lainnya di Bali. Sehingga agama agama tersebut dari segi SDM sudah terpenuhi jika membuat sebuah lembaga keagamaan. 
| SUPARTA | Strategi Pendidikan Toleransi Beragama...

Faktor yang ketiga adalah faktor ekonomi. Walaupun umatnya ada, SDM-nya pun ada tetapi dikarenakan tidak ada dana pembangunannya maka beberapa agama yang akan mendirikan lembaga keagamaan menjadi kandas. Untuk itu, beberapa agama ada yang mengaharapkan adanya kerjasama yang baik dengan pihak pemerintah dan umatnya dalam mengembangkan lembaga keagamaan. Jika memang sudah ada kerjasama ini maka dipastikan keinginan untuk mewujudkan lembaga keagamaan akan terealisasi sesuai dengan yang diharapkan.

Faktor yang keempat adalah faktor geografis. Ada beberapa agama khususnya agama Kristen yang akan membangun sebuah lembaga keagamaan, SDM-nya sudah siap, dananya sudah siap, namun terkendala dengan letak geografisnya. Maksudnya adalah jika umat disekitarnya sangat minim bahkan didominasi oleh umat beragama yang lain, maka mendirikan lembaga keagamaan akan sulit direalisasikan karena akan terkendala dengan izin. Sebab, jika dilanjutkan pendiriannya maka akan menimbulkan konflik horizontal. Jika terjadi konflik maka bukan kemaslahatan yang bisa didatangkan akan tetapi justru kemudharatan.

Atas dasar beberapa faktor tersebut maka lembaga keagamaan di Propinsi Bangka Belitung hanya ada beberapa agama saja. Pertama, Lembaga Keagamaan Umat Islam. Agama Islam termasuk agama mayoritas di Bangka Belitung. Selain memiliki umat yang paling banyak umat Islam juga memiliki SDM yang cukup banyak. Oleh sebab itu lembaga keagamaannya cukup banyak yang tersebar di beberapa kabupaten bahkan sampai ke desa desa. Adapun bentuk lembaganya adalah pondok pesantren baik pondok pesantren salaf maupun pondok pesantren khalaf. Pondok pesantren salaf tidak memiliki lembaga formal, yakni hanya khusus mengkaji kitabkitab klasik atau diorientasikan hanya mengkaji kitab kitab atau pelajaran keagamaan, hal ini disebabkan pesantren model ini memang bertujuan untuk membentuk para calon ustadz, kyai, da'i atau ulama. Sementara pondok pesantren khalaf atau modern adalah pondok pesantren yang sudah memadukan antara pelajaran agama dan pelajaran umum. Sehingga pada pesantren ini selain belajar ilmu ilmu keislaman juga ada sekolahsekolah formalnya seperti MI/SD, MTS/SMP, MA/SMA/SMK dan juga Perguruan Tinggi Islam (PTKI) atau umum. Di Bangka Belitung lembaga keagamaan umat Islam 
termasuk sudah lengkap mulai dari lembaga tingkat dasat sampai perguruan tinggi (IAIN Syaikh Abdurrahman Siddik).

Kedua, Lembaga Keagamaan Umat Kristen Protestean atau Katolik. Di Bangka Belitung umat kristen juga memiliki beberapa Lembaga. Namun demikian lembaga agama Kristen lebih menitikberatkan pada lembaga pendidikan yang sifatnya formal. Lembaga ini berada di beberapa kabupaten khususnya di pusat kota kabupaten. Seperti di pangkalpinang ada TK Kalam Kudus, SD Kanisius, SD Santamaria, ada SMP dan SMA Santo Yosep serta lain sebagainya. Begitu juga di Sungailiat, Tanjung Pandan, Muntok, Koba dan Toboali ada bebarapa lembaga SD, SMP dan SMAnya yang dikelola oleh yayasan yang berbasis agama Kristen. Namun demikian yang sekolah dibeberapa lembaga tersebut bukan hanya umat Kristen akan tetapi umat Islam dan agama lain-pun ada yang sekolah di lembaga tersebut misalnya di SMP dan SMA Santo Yosep Pangkalpinang dan SMA Setia Budi Sungailiat.

Ketiga, Lembaga Kegamaan Umat Budha, Hindu dan Konghucu. Untuk ketiga agama ini belum ada secara khusus lembaga keagamaan yang dikelola dengan model formal akan tetapi masih bersifat non formal. Misalnya untuk agama Budha sistem pembelajaran keagamaan lebih kepada sistem klasikal yakni dibentuk model kelas-kelas darma. Begitu juga dengan agama Hindu model pembelajaran keagamaanya masih bersifat kelas-kelas yang diadakan setiap minggu dua kali. Sama halnya dengan agama Konghucu pertemuan pembelajaran keagamaannya masih bersifat temporal. Hal ini disebabkan selain masalah kuantitas umat yang minim juga terkendala dengan SDM dan juga dana pembangunannya.

\section{Strategi Tokoh Agama Mendidik Kerukunan Beragama antar Agama dengan Pemerintah di Bangka Belitung}

Berdasarkan hasil wawancara dengan semua tokoh agama, baik Islam, Kristen Protestan, Katolik, Budha, Hindu dan Konghucu, semuanya mengatakan bahwa selama ini dengan pemerintah memiliki kerukunan yang sangat baik. Hal ini terbukti dengan adanya kerjasama yang baik antara agama dengan pemerintah melalui pembangunan lembaga-lembaga pendidikan keagamaan dan rumah-rumah ibadah. Pemerintah tidak pilih kasih, semua agama dibantu untuk membangun rumah-rumah ibadah mulai dari 
mesjid, greja, vihara, pura dan juga klenteng. Dalam ajaran Islam untuk baik dan taat kepada pemerintah secara tegas diajarkan dalam Al-Qur'an. Hal ini tertera dalam surat Annisa: 59 yang artinya Hai orang-orang yang beriman, taatilah Allah dan taatilah Rasul (nya), dan ulil amri di antara kamu. Kemudian jika kamu berlainan pendapat tentang sesuatu, Maka kembalikanlah ia kepada Allah (Al Quran) dan Rasul (sunnahnya), jika kamu benar-benar beriman kepada Allah dan hari kemudian. yang demikian itu lebih utama (bagimu) dan lebih baik akibatnya.

Berdasarkan ayat ini jelaslah bahwa Allah memerintahkan kepada semua yang beriman agar taat pada Allah dan Rasulnya secara Mutlak, karena didahului dengan kata "Athi'uu" namun untuk taat pada pemerintah tidak mutlak akan tetapi bersyarat karena tidak didahului kata 'athi'uu'. Artinya kemutlakan untuk taat pada pemerintah ketika pemerintah tersebut memang berada pada kebenaran, tetapi jika pemerintah berada dalam kesalahan dan kedzaliman maka ketaatan kita terhadap pemerintah menjadi tidak mutlak lagi, akan tetapi justru harus menasehatinya.

Dalam Agama Kristen Protestan berkaitan dengan ajaran baik tehadap pemerintah juga sangat dianjurkan. Hal ini seperti yang dikatakan oleh Heskia (pendeta) di Koba Bangka Tengah, ia mengatakan bahwa seluruh lembaga atau seluruh negara bisa ada dimuka bumi ini karena kehendak yang di atas (Allah). Bahkan dalam ajarannya ada perintah yang mengatakan "Hormatilah Rajamu, hormatilah pemerintahmu, yang akan memerintah kamu, meskipun tidak mengenakan kamu." Dengan demikian pahit atau manisnya keberadaan pemerintahmu saat ini maka tetap harus dihormati. Itulah sebabnya umat Protestan sampai saat ini tetap memiliki hubungan yang baik dengan pemerintah.

Begitu juga dengan agama Budha, selama ini seperti yang dikatakan Romo Budhy tokoh agama Budha di Tanjung Pandan Kabupaten Belitung, hubungan agamanya dengan pemerintah sangatlah baik. Bukti baiknya adalah ketika agama Budha membuat rumah Ibadah berupa Vihara pemerintah juga ikut andil dalam membangunnya dengan cara menyalurkan bnatuannya berupa dana hibah. Sehingga, sampai dengan saat ini hubungan agama Budha dengan pemerintah sangat baik.

Dalam agama Hindu juga demikian, menurut I Wayan Pasek, hubungan baik dengan pemerintah adalah kewajiban bagi setiap agama khususnya agama Hindu. Hal 
ini disebabkan kita hidup pun berada di wilayah kekuasaan pemerintahnya. Hubungan baik ini sudah pemerintah buktikan dengan adanya warga Bali yang semuanya beragama Hindu ditransmigrasikan di daerah Belitung. Semua fasilitas diberikan berupa sandang pangan dan papan, bahkan sekolah dan rumah ibadah pun di bantunya. Dengan demikian tiada kata lain bagi umat hindu di Belitung kecuali untuk selalu berbuat baik dan berhubungan baik dengan pemerintahnya.

Demikian juga dengan agama Konghucu, selama ini dirasakan hubungannya dengan pemerintah sangat harmonis. Hal ini terbukti walaupun umat Konghucu hampir semuanya warga keturunan Tionghoa atau China akan tetapi telah diakui sebagai pribumi. Terlebih lagi pada masa Gusdur ada pengesahan langsung terhadap agama Konghucu yang menjadi kebanggaan sendiri bagi para penganutnya. Memang tidak dapat dipungkiri bahwa hubungan umat konghucu dengan pemerintah sempat tidak harmonis ketika masa orde baru apalagi setelah terjadi peristiwa G30 S PKI. Namun demikian akhirnya kembali harmonis sejak KH. Abdurrahman Wahid (Gusdur) mengakui agama Konghucu termasuk agama yang diakui di Indonesia.

\section{Konsep Toleransi Bergama dalam Perspektif Kitab Suci Masing-masing Agama}

Kerukunan sering dikenal dengan istilah populernya dengan sebutan toleransi. Sementara toleransi berasal dari kata Latin tolerare yang berarti bertahan atau memikul. Dengan demikian, toleran diartikan dengan saling memikul walaupun pekerjaan itu tidak disukai atau memberi tempat kepada orang lain, walaupun kedua belah pihak tidak sependapat. Berarti tidak ada yang namanya memaksakan kehendak sendiri atau kehendak orang lain supaya sesuai dengan kehendaknya masing-masing.

Persamaan kata toleransi dalam bahasa Arab adalah tasamuh yang berarti saling mengizinkan dan saling memudahkan. Artinya memberi ruang dalam hati kita untuk menerima perbedaan baik pendapat maupun pemikiran dari orang lain. Dengan demikian, toleransi berarti sikap menenggang, membiarkan, membolehkan, baik berupa pendirian, kepercayaan, dan kelakuan yang dimiliki seseorang atas yang lainnya.

Pada pembahasan ini akan dijelaskan tentang toleransi atau konsep kerukunan yang ada pada setiap agama masing-masing. Hal ini disebabkan setiap agama memiliki konsep cinta, kasih sayang, dan perdamaian, sehingga menjadi pelopor terciptanya 
kehidupan yang damai dan hidup harmonis, saling menghormati, saling mencintai, dan saling menghargai hak dan kewajiban masing-masing. Bahkan, setiap agama memiliki kitab suci atau pedoman hidup yang semua berorientasi pada kebaikan , ketentraman dan keselamatan hidup yang diyakini oleh penganutnya masing-masing. Berati keinginan untuk hidup rukun dan damai ini merupakan ajaran universal yang di setiap agama ada tuntunannya. Untuk lebih jelas mengenai konsep kerukunan atau toleransi dalam perspektif agama masing-masing akan dijelaskan di bawah ini:

\section{Konsep Kerukunan atau Toleransi dalam Agama Islam}

Ketika Nabi Muhammad hijrah ke kota Madinah, Nabi melihat kenyataan adanya pluralitas agama. Di kota tersebut memiliki agama yang beranekaragam mulai dari agama Yahudi, agama Nasroni, Majuzi dan bahkan para Kaum Musyrikin lainnya yang tidak memiliki agama. Semua agama yang ada di kota Madinah saat itu diberikan kebebasan untuk memeluk dan mengamalkan ajarannya. Hal ini seperti yang tercantum dalam Pasal 25 Piagam Madinah menyebutkan bahwa bagi orang-orang Yahudi agama mereka dan bagi orang Islam agama mereka. Pasal 20 Piagam Madinah mengisyaratkan bahwa orang-orang musyrik atau kafir Madinah tidak dinyatakan sebagai musuh kaum Muslimin. Kebebasan beragama pada masa Nabi Muhammad s.a.w. juga ditunjukkan dengan adanya kebebasan dalam melakukan propaganda keagamaan. Ajaran tentang kerukunan dalam Islam banyak dijelaskan dalam Al-Qur'an maupun Hadits Rasulullah saw. Dalam Al-Qur'an termaktub dalam beberapa surat dan ayat. Adapun yang tercantum dalam Al-Qur'an yaitu: Dan kami Telah turunkan kepadamu Al Quran dengan membawa kebenaran, membenarkan apa yang sebelumnya, yaitu kitab-kitab (yang diturunkan sebelumnya) dan batu ujian terhadap kitab-kitab yang lain itu; Maka putuskanlah perkara mereka menurut apa yang Allah turunkan dan janganlah kamu mengikuti hawa nafsu mereka dengan meninggalkan kebenaran yang Telah datang kepadamu. untuk tiap-tiap umat diantara kamu, kami berikan aturan dan jalan yang terang. sekiranya Allah menghendaki, niscaya kamu dijadikan-Nya satu umat (saja), tetapi Allah hendak menguji kamu terhadap pemberian-Nya kepadamu, Maka berlomba-lombalah berbuat kebajikan. Hanya kepada Allah-lah kembali kamu semuanya, lalu diberitahukan-Nya kepadaти apa yang Telah kamu perselisihkan itu. 
Tercantum juga dalam Firman Allah Surat Al-Hujurat : 13;

Hai manusia, Sesungguhnya kami menciptakan kamu dari seorang laki-laki dan seorang perempuan dan menjadikan kamu berbangsa-bangsa dan bersuku-suku supaya kamu saling kenal-mengenal. Sesungguhnya orang yang paling mulia diantara kamu disisi Allah ialah orang yang paling taqwa diantara kamu. Sesungguhnya Allah Maha mengetahui lagi Maha Mengenal.

Tercantum juga dalam Al-Qur'an Surat Ar-Rum:22;

Dan di antara tanda-tanda kekuasaan-Nya ialah menciptakan langit dan bumi dan berlain-lainan bahasamu dan warna kulitmu. Sesungguhnya pada yang demikan itu benar-benar terdapat tanda-tanda bagi orang-orang yang Mengetahui.

Bahkan dalam Hadits pun disebutkan;

"Hai segenap manusia, sebarkanlah salam, sedekahkanlah makanan,dan sambunglah tali persaudaraan (silaturrahmi) serta shalatlah di kala manusia tidur di kegelapan malam, niscaya kamu masuk surga dengan penuh kedamaian” (HR. Tirmidzi).

Berdasarkan beberapa Ayat dan Hadits di atas memberikan makna bahwa Agama Islam mengajarkan agar umatnya untuk berbuat baik dan bertindak adil kepada siapapun yang tidak memerangi umat Islam karena agama yang dianut. Islam mengutamakan terciptanya suasana perdamaian, hingga timbul rasa kasih sayang di antara umat Islam dengan umat beragama lain .Kerjasama yang baik antara umat Islam dan umat beragama lain tidaklah menjadi halangan dalam Islam. Hal ini disebabkan Islam diturunkan bukan saja rahmat bagi umat Islam akan tetapi harus juga menjadi rahmat bagi seluruh alam. Hal ini sesusai dengan Firman Allah dalam Al-Qur'an :

Dan tidaklah aku utus engkau wahai Muhammad kecuali sebagai rahmat bagi seluruh alam.

\section{Konsep Kerukunan dalam Perspektif Agama Hindu}

Kemajemukan atau keberagaman bukan hanya sebagai sebuah realitas sosial. UUD 1945 menyatakan dgn jelas bahwa negara menjamin kemerdekaan tiap-tiap penduduk untuk memeluk agamanya masing-masing dan untuk beribadat menurut agama dan kepercayaannya. Karena itulah ditegaskan bahwa semua agama memiliki hak yang sama untuk tumbuh dan berkembang, termasuk pemeluknya untuk menjalankan agamanya secara bebas. Pemeluk agama tertentu tidak boleh memaksa 
| SUPARTA | Strategi Pendidikan Toleransi Beragama...

pemeluk agama lainnya untuk pindah agama sebagaimana realita yang kita lihat selama ini. Setiap orang memiliki hak dasar untuk memeluk agama yang berarti kebebasan dan kewenangan seseorang untuk menganut suatu agama yang tercantum dalam Pustaka Suci Veda, khususnya Bhagavadgita.

Umat Hindu menghormati kebenaran dari manapun datangnya dan menganggap bahwa semua agama bertujuan sama, yaitu menuju Tuhan, namun dengan berbagai sudut pandang dan cara pelaksanaan yang berbeda. Hal ini diuraikan dalam Bhagavadgita IX.29 yang berbunyi:

samo 'ham sarvabhuutesu

na me dvesyo 'sti na priyah

ye bhajanti tu maam bhaktyaa

mayi te tesu caa 'py aham

Artinya : Aku bersikap adil pada semua makhluk, tidak ada yang paling Ku-benci ataupun yang paling Ku-kasihi, akan tetapi mereka yang berbhakti kepada-Ku, maka dia ada dalam Diri-Ku dan Aku ada dalam dirinya. Begitu pula Bhagavadgita IV.11 yang menyatakan
ye yathaa mam prapadyante
tams tathaiva bhajamy aham
mama vartmanuvartante
manusyah partha sarvasah

Artinya: Jalan manapun yang ditempuh seseorang mendekati-Ku, Aku terima, melalui banyak jalan manusia mengikuti jalan-Ku, wahai Arjuna. Selanjutnya Bhagavadgita VII.21 juga menyatakan:

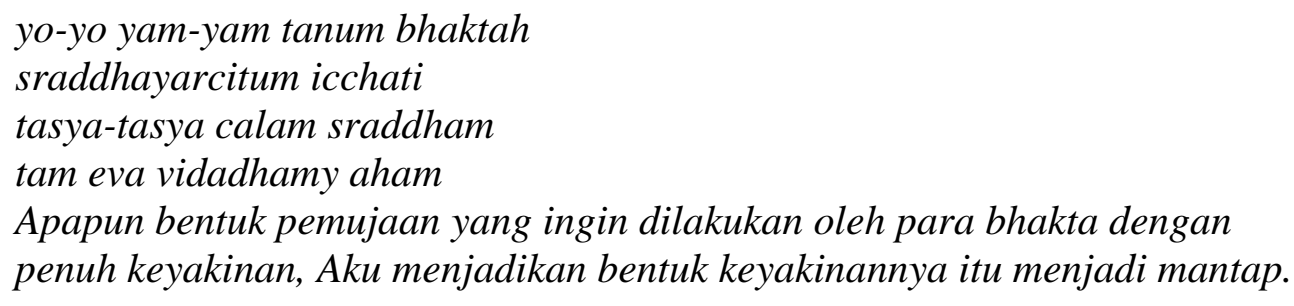

Pandangan Hindu tentang kebhinekaan dan kewarganegaraan juga tertuang dalam Kitab Sutasoma karya Mpu Tantular pada jaman Majapahit saat pemerintahan Raja Hayam Wuruk. Dalam kitab ini terdapat ungkapan yang dipetik oleh para pendiri bangsa yaitu pada pupuh 139 (bait V) yang dijadikan motto dalam Garuda Pancasila sebagai lambang Negara Kesatuan Republik Indonesia, yang selengkapnya berbunyi:

hyang buddha tanpahi siwa rajadewa 
rwaneka dhatu winuwus buddha wiswa

bhineki rakwan ring apan kena parwanesen

mangkana jiwatman kalawan siwatattwa tunggal

bhinneka tunggal ika tan hana dharma mangrwa

Artinya : Hyang Buddha tiada berbeda dengan Siwa Mahadewa, keduanya merupakan sesuatu yang satu, tiada mungkin memisahkan satu dengan lainnya, berbeda keadaannya namun satu jua adanya, karena tiada kebenaran yang mendua. Semboyan "bhinneka tunggal ika" yang telah ditorehkan pada Garuda Pancasila sebagai lambang NKRI telah menginspirasi banyak orang bahwa sesungguhnya umat manusia di Indonesia dapat dipersatukan dalam wadah keberagaman. Atharwaweda VII.52.1 yang berbunyi;

Samjnanam nah svebhih samjnanam aranebhih, samjnanam asvina yuvam ihasmasu ni yacchatam

Artinya: Hendaknya harmonis diantara kamu baik dengan orang-orang yang dikenal maupun dengan orang asing sekalipun. Semogalah Dewa Asvin memberikan anugerah untuk keharmonisan. Bahkan Hindu memandang bahwa orang hina dan binatang sekalipun adalah sama, sebagaimana dinyatakan dalam Bhagavadgita V.18:

vidya vinaya sampanne

brahmane gavi hastini

suni caiva svapake ca

panditah sama darsinah

Artinya: Orang bijaksana melihat semuanya sama, baik dalam melihat brahmana budiman nan rendah hati maupun seekor sapi, gajah, dan anjing ataupun orang yang rendah sekalipun. Selain itu, Hindu dikenal istilah santa jagadhita atau sukritama, yaitu masyarakat religius yang hidup dalam kedamaian dan ketenteraman. Dalam Kitab Weda dikatakan "Wahai umat manusia! Bersatulah dan rukunlah kamu seperti menyatunya para dewata. Aku telah menganugerahkan hal yang sama kepadamu. Oleh karena itu, Ciptakanlah persatuan di antara kamu” (Atharvaveda III.30.4).

\section{Konsep Kerukunan dalam Perspektif Agama Budha}

Wahai umat manusia! Milikilah perhatian yang sama. Tumbuhkan saling pengertian di antara kamu. Dengan demikian engkau dapat mewujudkan kerukunan dan kesatuan” (Rigveda X. 191.4). 
| SUPARTA | Strategi Pendidikan Toleransi Beragama...

Agama Buddha juga cinta perdamaian, Untuk mewujudkan perdamaian, Buddha memiliki konsep metta, yakni cinta kasih universal. Metta lebih luas dan lebih mulia dari semua bentuk persaudaraan yang sempit. Metta tidak dibatasi oleh peraturanperaturan, bidang-bidang; tidak mempunyai rintangan dan penghalang; tidak mengadakan perbedaan.

Sabda Sang Buddha:"Segala keadaan kita adalah hasil dari apa yang kita pikirkan. Dijadikan oleh pikiran kita dan ditentukan oleh pikiran kita. Kalau kita berkata dan berbuat dengan pikira positif, yakni pikiran yang penuh dengan cinta kasih, belas kasihan dan simpati terhadap kebahagiaan orang lain, adil dan bijaksana, maka kebahagiaan dan kedamaian akan senantiasa mengikuti kita" Seorang yang berada di tengah-tengah orang yang membenci, hendaklah orang itu hidup bebas dari kebencian". "Kebencian tidak akan berakhir kalau dibalas dengan kebencian. Kebencian akan berakhir kalau dibalas dengan cinta kasih atau dengan tidak membenci". "Kebencian tak dapat dipadamkan dengan kebencian. Hanya sikap tidak membenci yang dapat mengakhirinya. Inilah hukum yang abadi” (Dhammapada, I:5).

\section{Konsep Kerukunan dalam Perspektif Agama Kristen}

Dalam agama Kristen, ada keyakinan bahwa Yesus adalah tokoh cinta damai dan anti kekerasan. Karena Yesus adalah pembawa damai, maka umat Kristiani juga terpanggil untuk menjadi pembawa damai. Dalam hal ini Yesus bersabda:

"Berbahagialah orang yang membawa damai karena mereka akan disebut anak-anak Allah" (Matius 5:8).

Menurut Daniel tokoh agama Kristen di Bangka Selatan, mengatakan bahwa jika semua umat mengamalkan ajaran agamanya masing-masing termasuk didalamnya umat Kristen dipastikan tidak akan ada pertikaian antara umat bergama. Apalagi dalam agama Kristen seperti yang diungkapkan dalam Matius 5:8 orang yang membawa kedamaian maka termasuk anak-anak Allah.

\section{E. Implikasi Toleransi Beragama terhadap Keutuhan NKRI di Bangka Belitung 1. Ajaran Toleransi Beragama Berimplikasi Cinta pada Negara}

Berdasarkan hsil wawancara pada setiap tokoh Agama, mereka sepakat bahwa tiap ajaran agamanya memiliki konsep untuk mencintai negaranya. Dalam ajaran Islam 
para ulama Nusantara menanamkan rasa nasionalisme pada umatnya dengan slogan "Hubbul Wathan Minal iiman (cinta tanah air bagian dari iman. Hal ini memiliki makna tersirat bahwa jika seseorang tidak memiliki rasa cinta terhadap negaranya maka berarti ada sebagain imannya yang kurang.

Dalam umat Islam cinta Tanah air ini telah terbukti ketika masa penjajahan. Semua ulam dan para santrinya berjuang dengan segenap jiwa dan raganya demi mebela negaranya. Turunnya para ulama dan semua sntrinya untuk berjuang melawan penjajahan dimuka bumi indonesia inilah sebagai bukti bahwa cinta tanah air itu bagian dari Iman. Sehingga banyak dari pahlawan negara yang berasal dari umat Islam, seperti Pangeran Diponegoro, Jendral Sudirman, Tuanku Imam Bonjol, Cut Nyakdien, Bung Tomo, Sultan Hasanudin, dan lain sebagainya.

Dalam Agama Kristen ajaran untuk mencintai negaranya pun tertcantum adalam kitabnya. Hal ini diunhkapkan bahwa setiap umat kristen harus menghormati pemerintah dan negaranya. Adapun perintah itu berbunyi " hormatilah rajamu, hormatilah pemerintahmu yang akan memerintahmu walaupun tidak mengenakkan kamu". Disinilah akhirnya umat kristen selalu berusaha untuk menghormati pemerintah, ketika menghormati pemerintah berarti mencintai juga tempat yang dperintahnya yaitu negara.

\section{Ajaran Toleransi Beragama Berimplikasi Mempertahankan atau Keutuhan}

\section{NKRI}

Semua Tokoh Agama sepakat NKRI akan tetap ada jika falsafah negara berupa pancasila masih tetap dipertahankan. Selama ini telah terbukti bahwa pancasila dapat menyatukan bukan hanya semua suku ras dan etnis akan tetapi juga agama. Bahkan menurut agama hindu bahwa istilah pancasila tersebut berasal dari bahasa agama mereka, begitu juga dengan semboyan Bhineka Tunggal Ika. Oleh sebab itu, selama pancasila masih dijadikan falsafah negara maka para tokoh agama optimis NKRI akan tetap bisa dipertahankan atau masih utuh. Namun demikian, jika falsafah ini dirubah kemungkinan darisinilah berawal perpecahan diantara suku dan agama akan terjadi. Selain itu, semua agama merasakan bahwa NKRI adalah milik bersama yang harus dijaga keutuhannya. Sebab, bisa jadi saat ini ada beberapa oknum yang tidak 
| SUPARTA | Strategi Pendidikan Toleransi Beragama...

menginginkan NKRI ini utuh, sehingga mereka membuat makar atau propaganda adu domba dimana-mana. Tentunya tujuan akhirnya menginginkan NKRI ini terpecah bahkan mungkin dihancurkan agar tidak bersatu lagi.

Atas dasar inilah maka semua para tokoh agama di Bangka Belitung, memiliki persepsi yang sama tentang menjaga keutuhan NKRI. Adanya FKUB termasuk salah satu media untuk menjaga keutuhan NKRI agar persatuan dan kesatuan tetap terjaga. Sebab, FKUB ini dibentuk untuk menyatukan seluruh persepsi agama yang ada di Bangka Belitung.

\section{F. Kesimpulan}

Strategi para tokoh agama dalam menjaga kerukunan beragama di Bangka Belitung terdiri dari tiga; Pertama, strategi mendidik umat dalam kerukunan internal umat beragama. Dalam hal ini semua para tokoh agama masing-masing sepakat membina umatnya agar hidup rukun dan damai. Tentunya arahan ini sesuai dengan ajaran kitabnya masing-amsing. Kedua, strategi mendidik umatnya agar rukun dengan sesama agama yang lainnya. Mereka berusaha maksimal agar setiap uamtnya selalu menghargai dan menghormati agama yang lainnya, tidak boleh mamaksa kehendak agamanya, tidak boleh saling menjelek-jelekkan gama yang lain dan juga tidak boleh menyakiti umat agama lainnya.

Hal ini pun tercantum dalam jarannya kitab suci disetiap agama masing-masing. Ketiga, strategi mendidik umatnya agar rukun dengan pemerintah. Dari hasil wawancara disimpulkan bahwa semua ajaran agama memerintahkan agar selalu berhubungan baik dan menghormati pemerintahnya. Hal ini disebabkan semuanya menyadari bahwa kita hidup dinegara yang sama yaitu negara Indonesia dalam satu kekuasaan dan pemerintahan. Maka menghormati, menghargai dan mamtuhi aturan pemerintah adalah sebuah keharusan.

Strategi untuk menjaga keutuhan NKRI juga disepakati oleh semua tokoh agama. Mereka sepakat jika faksafah Indonesia adalah Pancasila, jangan dirubah lagi. Hal ini disebabkan selama ini yang dapat menyatukan semua ajaran agama yang ada di Indonesia adalah Pancasila. Oleh karena itu NKRI menjadi utuh dan akan tetap utuh jika semua agama menjaga Pancasila. 


\section{Daftar Pustaka}

Afifuddin dan Saebani, Beni Ahmad, 2009, Metodologi Penelitian Kualitatif, Bandung: Pustaka Setia.

Asry, M. Yusuf, Editor, 2012, Gerakan Dakwah Islam dalam Perspektif Kerukunan Umat Beragama, Jakarta: Puslitbang kehidupan keagamaan Badan Litbang dan Diklat Kementerian Agama RI.

Darmiko, dkk, 2011, Islam Dan Kerukunan Umat Antar Agama (Studi Kasus Kerukunan umat antar agama di Provinsi Kepulauan Bangka Belitung, STAIN SAS BABEL

Durkheim, Emile 1993, Dasar-Dasar Sosial Agama dalam Roland Robertson (ed) Agama dalam Analisa dan Interpretasi Sosiologis. Terjemahan A.F. Saifuddin, Jakarta: Rajawali Press.

Machasin, 2011, Islam Dinamis Islam Harmonis Lokalitas Pluralisme Terorisme, Yogyakarta: LKiS.

Hasan, Noorhaidi, 2012, dakwah, aktivitas diskursif dan tantangan globalisasi, Jakarta: Puslitbang Kehidupan Keagamaan Kemenag RI.

Herdiawanto, Heri dan Hamdayama, Jumanta, 2010, Cerdas, Kritis, dan Aktif Berwarganegara, Jakarta: Erlangga.

http://www.kemendagri.go.id/pages/profil-daerah/provinsi/detail/19/kepulauan-bangkabelitung

Kymlicka, Will, 1995, Multicultural Citizenship. A Liberal Theory of Minority Rights, Oxford: Oxford University Press.

Muhaimin, MA. Et al. 2007, Kawasan dan Wawasan Studi Islam, Jakarta: Kencana.

Madjid, Nurcholish, 2008, Islam Kemodernan dan Keindonesiaan, Bandung: PT. Mizan Pustaka.

Mudyahardjo, Redja, 2001, Filsafat Ilmu Pendidikan, Suatu Pengantar, Bandung: Ramaja Rosdakarya.

Mahfud, Choirul, 2008, Pendidikan Mutikultural, Yogyakarta: Pustaka Belajar.

Moleong, Lexy J. 1989, Metodologi Penelitian Kualitatif, Bandung: Remaja Rosda Karya.

Nazir, Mohd, 1983, Metode Penelitian, Jakarta: Ghalia Indonesia. 
| SUPARTA | Strategi Pendidikan Toleransi Beragama...

Nawawi, Hadari, 1995, Metodologi Penelitian Bidang Sosial, Yogyakarta: Gajahmada University Press.

Suparlan, Tarsudi, 1998, Penelitian Agama Islam: Tijauan Disiplin Antropologi" dalam Mastuhu dan Deden Ridwan (ed), Tradisi Baru Penelitian Agama Islam: Tinjauan Antar Disiplin Ilmu, Jakarta: Pusjarlit dan Nuansa.

Suryabrata, Sumadi, 2006, Metodologi Penelitian, (Jakarta: Raja Grafindo Persada.

Zulkifli, 2008, Antropologi Sosial Budaya, Yogyakarta: Graha Guru.

Wawancara dengan beberapa Tokoh Lintas Agama di Bangka Belitung 